\title{
Effects of Storage Period, Marketing Channels and Season on Internal and External Quality of Commercial Table Eggs Marketed in Riyadh City (Saudi Arabia)
}

-Author(s)

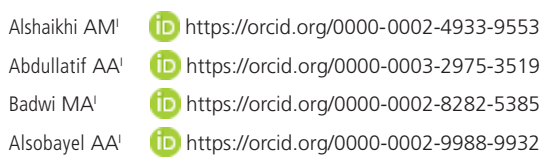

Alsobayel AA' (iD) https://orcid.org/0000-0002-9988-9932

Animal production Dept. College of Food and Agricultural Sciences. King Saud University, P.O. Box 2460, Riyadh11451, Saudi Arabia.

\section{nail Address}

Corresponding author e-mail address Ali M. Alshaikhi

Animal production Dept. College of Food and Agricultural Sciences. King Saud University, P.O. Box 2460, Riyadh11451, Saudi Arabia. Email: asheikhi@ksu.edu.sa

\section{EKeywords}

Commercial Table eggs, Egg quality.

Marketing channels, Season, Storage period.
Submitted: 09/June/2020

Approved: 22/November/2020

\section{ABSTRACT}

Very sparse information is available regarding quality of commercial Table eggs marketed in Riyadh city. The objective of the current study was to evaluate egg quality by determining the internal and external traits of commercial Table eggs marketed in different marketing channels during the summer and winter. Commercial eggs $(n=1440)$ were bought from four different supermarkets and groceries during the winter and summer season 2018-2019. A total of 30 eggs were collected monthly from each marketing channel in the winter and summer. Then, individually numbered, weighed and randomly broken down into three empirical groups and stored for 0, 7 or 14 days. The outcomes show that seven and fourteen days of storage led to significant decrease in Haugh unit values, yolk index, specific gravity, shell thickness and shell weight per unit of surface area, and increase in yolk color grade, yolk albumin ratio, yolk and albumin $\mathrm{pH}$ and air cell depth. Eggs acquired from supermarkets had significantly higher Haugh unit values and yolk index, and lower yolk color grades, shell density and air cell depth, than those bought from groceries. Eggs that were collected in winter season are found to have significantly higher Haugh unit values, yolk index, specific gravity, shell thickness, shell density, shell weight per unit of surface area and yolk color, and lower, yolk albumin ratio, air cell depth, albumin and yolk pH than those acquired in the summer season eggs. This study showed that the storage period, marketing channels and season play a significant role in affecting quality traits of Table eggs, also those procured from supermarkets and in the winter presented better quality than those found in groceries or in the summer, respectively.

\section{INTRODUCTION}

Hen's eggs have a natural balance of essential nutrients, besides being generally considered an important constituent of human food (Opaliński, 2017). Egg quality has a genetic basis and can also be affected by non-genetic factors such as age of the bird, feeding, season, transportation, storage period and conditions. Eggs produced in farms might have a good quality, but poor handling and storage conditions on farms and in channels of marketing could lead to losses in egg quality (Al-Obaidi et al., 2011).

The most important changes in internal or external egg quality during storage length or handing practices are due to weight loss by water evaporation (Calik 2013; Samli et al., 2005), power of Hydrogen of albumen and yolk increases and Haugh unit values reduce, while carbon acid dissociates (Mohiti-Asli et al., 2008; Monira et al., 2003). These fluctuations are the consequence of water movement through the vitelline membrane from albumen to yolk due to weakness of vitelline membrane (Jones 2007; Kralik et al., 2014). 
Alshaikhi AM, Abdullatif AA, Badwi MA, Alsobayel AA
Effects of Storage Period, Marketing Channels and Season on Internal and External Quality of Commercial Table Eggs Marketed in Riyadh City (Saudi Arabia)
The various production systems and the low production cost of eggs make them widely accessible to rural and urban populations (Moula 2012). Moreover, they are accepted globally and not subjected to major cultural or religious prohibitions (Bessadok et al., 2003). Furthermore, fluctuations in consumption habits and lifestyle, accompanied by the development of fast food, dramatically increased demand. In fact, eggs are agreeable ingredients in many food items.

Since 1980, the production and consumption of Table eggs in Saudi Arabia have witnessed a dramatic and continuous increase. Annual egg production increased from 3 billion in 2007 to 5 billion eggs in 2017, and per capita egg consumption increased for the same period from 142 to 158 eggs respectively (GASTAT, 2017). In Saudi Arabia, commercial Table eggs are mainly marketed in supermarkets, poultry shops and grocery stores. In general, Saudi's families purchase eggs by tray, which contains 30 eggs, store it in the refrigerator and consume it within one to two weeks.

In the meantime, very sparse information is available regarding quality characteristics of locally produced commercial eggs. The objective of the current study was to evaluate egg quality by determining the internal and external traits of commercial Table eggs marketed in Riyadh city during the winter and summer seasons.

\section{MATERIALS AND METHODS}

Commercial Table eggs ( $n=1440$ ) were bought from four supermarkets and four grocery stores located in different areas of Riyadh city through the winter (December, January and February) and the summer (July, August and September) 2018- 2019. Thirty eggs were monthly collected from each channel of marketing in the winter and summer. Then, separately numbered, weighed to the nearest $0.1 \mathrm{~g}$. and randomly broken down into three empirical groups of 40 eggs (replicates) and stored for 0,7 or 14 days. The eggs in the different experimental groups were either immediately analysed (Control, time zero), stored for 7 or 14 days in the refrigerator at $4-6{ }^{\circ} \mathrm{C}$ and $40-60 \%$ $\mathrm{RH}$.

\section{Measurements}

Eggs of each group were broken out on a bench glass at the end of the storage days to determine the yolk height and diameter (average of breadth and length) in millimetre were measured by speedometer and a Vernier caliper to calculate yolk index according to Equation 1, Haugh unit values were directly assessed using micrometre adjustable to egg weight, and directly gives Haugh unit value (Haugh 1937), yolk weight, albumen was discarded and the yolk was rolled on a damp paper towel to remove adhering albumen and weighed, albumen weight was calculated according to equation 2, yolk color was measured by Roch Color Scale which has 15 colour grades from very pale to deep yellow (North \& Bell 1990). Yolk ratio were calculated according to Equation 3, while albumen and yolk pH, were measured immediately using a calibrated $\mathrm{pH}$ meter (H12212 pH Meter, HANNA Instruments),

YIND $=($ Average yolk height $(\mathrm{mm}) /$ average yolk length $(\mathrm{mm})) * 100$ (Equation 1)

AW $(g)=$ whole egg weight - (yolk weight + dry shell weight) (Equation 2)

$\mathrm{Y} / \mathrm{A}=$ (yolk weight / albumin weight) (Equation 3)

Stored eggs were re-weighed at the end of the storage period adjacent 0.1 grams, air cell depth (AC) was measured in millimetre by using candling light and thin plastic ruler, specific gravity (SG) was measured by the method of Archimedes (North \& Bell 1990) as described in equation 4, the egg length and breadth of the eggs were measured with digital calipers to determined shape index (SI) by using the equation 5 ,

SG $=$ (Shell weight / (egg weight of air- egg weight in water) (Equation 4)

SI = (egg width / egg length)*100 (Equation 5)

The egg shell were washed carefully to remove albumen and dried at room temperate for one day, and individually weighed next to 0.1 grams, shell thickness was expressed in $\mathrm{mm} \times 10$ and measured at three locations, middle and both side of each egg with membrane using dial touch micrometre, egg surface area $(\mathrm{cm} 2)$ was calculated according to Equation 6 (Carter 1975), where (EW) egg weight (g) and shell density were calculated using Equation 4 (Curtis et al., 1985).

\section{$\mathrm{SA}(\mathrm{cm} 2)=3.9782 * \mathrm{EW}^{0.7056}$ (Equation 6)}

SD $\left(\mathrm{g} . \mathrm{cm}^{-3}\right)=$ Shell weight $(\mathrm{g}) /\left[\left(\right.\right.$ surface area, $\left.\mathrm{cm}^{2}\right)$ $\times$ (shellthickness, cm)] (Equation 7)

\section{Statistical analysis}

Data of this study were subjected to statistical analysis three-way ANOVA using the General Linear Models procedures of SAS software computer programme (SAS 2009) using the following model:

$$
\underset{i \mathrm{jk}}{\mathrm{Y}_{\mathrm{ijk} k}}+\mu+\varepsilon_{\mathrm{ijkl}}=\mathrm{C}_{\mathrm{i}}+\mathrm{S}_{\mathrm{j}}+\mathrm{ST}_{\mathrm{k}}+(\mathrm{CS})_{\mathrm{ij}}+(\mathrm{CST})_{\mathrm{ik}}+(\mathrm{SST})_{\mathrm{jk}}+(\mathrm{CST})
$$

Where, $Y_{i j k}$ is the $I^{\text {th }}$ observation of the $i^{\text {th }}$ marketing channels $j^{\text {th }}$ season and $k^{\text {th }}$ storage period, $\mu=$ overall 
Alshaikhi AM, Abdullatif AA, Badwi MA, Alsobayel AA
Effects of Storage Period, Marketing Channels and Season on Internal and External Quality of Commercial Table Eggs Marketed in Riyadh City (Saudi Arabia)

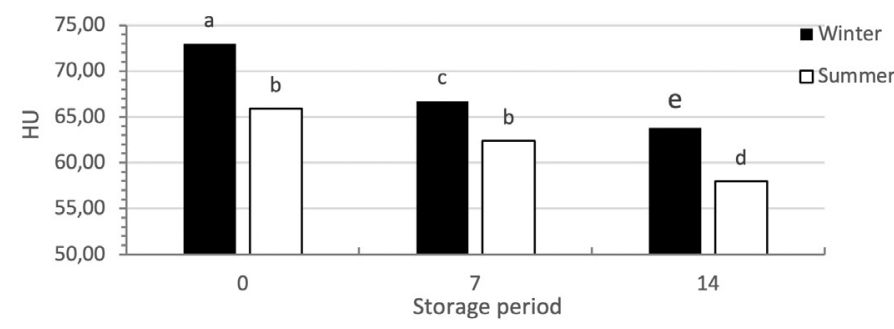

Figure $\mathbf{2}$ - The interaction effect of season and storage period on Haugh unit values

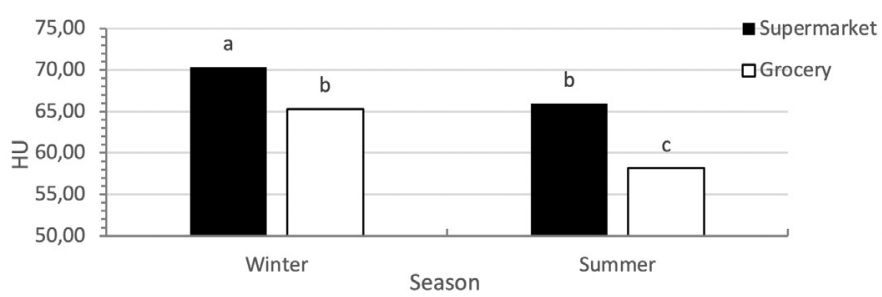

Figure 3 - The interaction effect of season and marketing channel on Haugh unit values.

\section{Yolk index (YIND)}

It appears from the results in Table 1 that storage period, channels of marketing, season and their interaction had a significant $(p \leq 0.05)$ effect on YIND, which was significantly reduced with increased storage days. Eggs bought from supermarkets or in the winter had significantly $(p \leq 0.05)$ higher YIND than those acquired from grocery stores or in the summer, respectively (Table 1). Eggs acquired from the supermarket in the winter had significantly $(p \leq 0.05)$ the highest YIND, whereas those acquired from the grocery in the summer had the lowest values during the different storage periods. Moreover, eggs bought from the supermarket in the winter and not stored had $(p \leq 0.05)$ the highest YIND, while those acquired from the grocery in the summer and sored for 14 days had the lowest value (Figure 4).

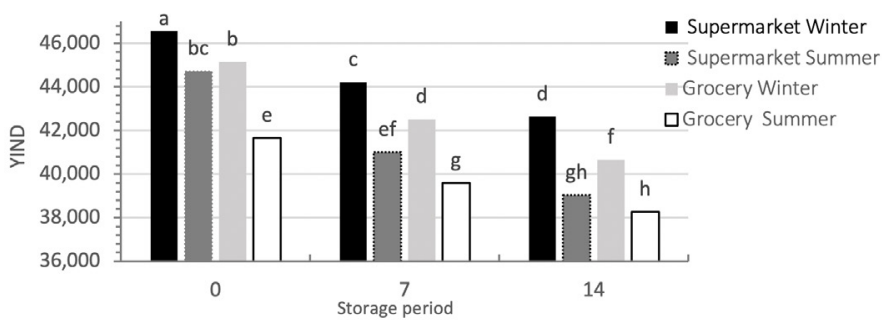

Figure 4 - The interaction effect of storage period, marketing channels and season on yolk index.

\section{Yolk colour grade (YCLR)}

The results in Table 1 demonstrate that storage length, marketing channel, season and the interaction between marketing channel and season had a significant $(p \leq 0.01)$ effect on $Y C L R$, which increased with increased storage period. Moreover, Eggs

Figure 1 - The he interaction effect of marketing channel and storage period on Haugh unit values. 
Alshaikhi AM, Abdullatif AA, Badwi MA, Alsobayel AA

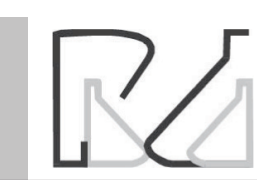

procured from grocery or winter had significantly $(p \leq 0.01)$ higher YCLR than those acquired from supermarkets in the summer, respectively. Figure 5 displays that eggs acquired from grocery stores in the winter and summer had significantly $(p \leq 0.05)$ higher YCLR than those obtained from supermarkets in the winter and summer, respectively. On the other the hand, eggs procured from supermarket stores in the summer had significantly $(p \leq 0.05)$ the lowest YCLR value.

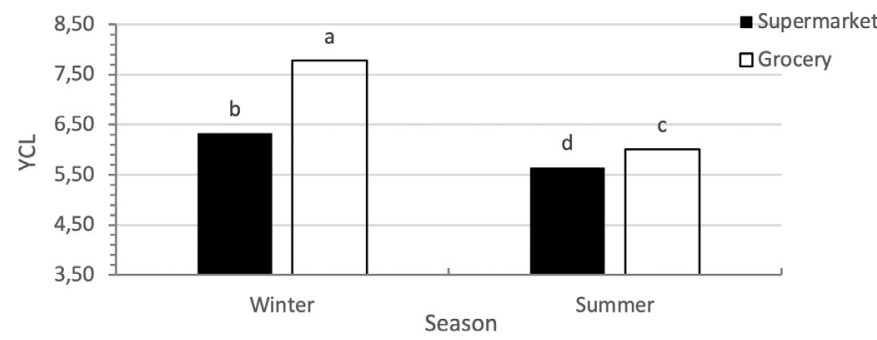

Figure $\mathbf{5}$ - The interaction effect of season and marketing channel on yolk color grade.

\section{Yolk albumin ratio (Y/W)}

The results in Table 1 state that storage period, season and the interaction between marketing channels and season had a significant $(p \leq 0.05)$ effect on $Y M$, which increased with increased storage days. Eggs bought in the summer had a significant $(p \leq 0.05)$ higher $Y M$ compared to those procured in the winter and eggs bought from the supermarket and grocery had statistically similar values. Figure 6 shows that eggs procured from grocery stores had significantly $(p \leq 0.05)$ higher $Y M$ than those bought from supermarket stores in the summer, but eggs bought from both stores in the winter had statistically similar values.

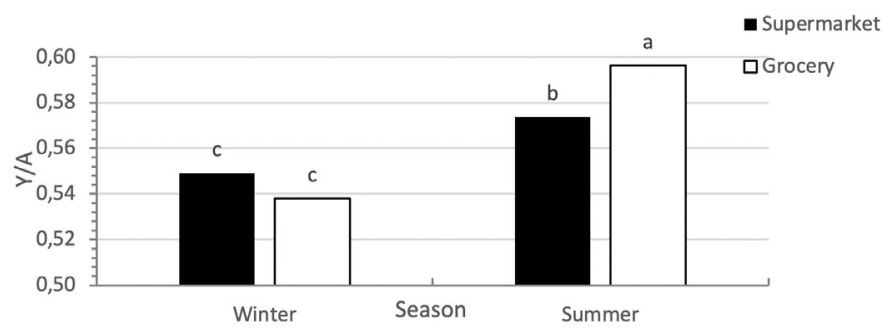

Figure $\mathbf{6}$ - The interaction effect of season and marketing channel on yolk albumin ratio.

\section{Yolk pH (YpH)}

Table 1 indicates that storage period, season and interaction between channels of marketing and season significantly $(p \leq 0.01)$ affected $\mathrm{YpH}$, which increased with increased storage length, and eggs obtained in the summer season had significantly $(p \leq 0.01)$ greater $\mathrm{YpH}$ compared to those bought in the winter (Table $1)$, and the eggs bought from supermarket and
Effects of Storage Period, Marketing Channels and Season on Internal and External Quality of Commercial Table Eggs Marketed in Riyadh City (Saudi Arabia)

grocery stores had statistically similar values. Figure 7 specifies that eggs purchased from supermarket stores in the summer and winter seasons had statistically similar $\mathrm{YpH}$, whereas those from grocery stores were significantly $(p \leq 0.05)$ irrespective of storage period, the uppermost and lowermost values for summer and winter seasons, respectively.

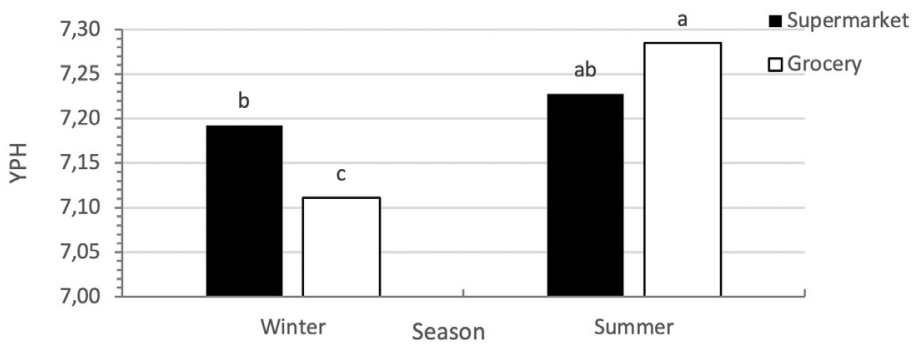

Figure 7 - The interaction effect of season and marketing channel on yolk pH (YPH).

\section{Albumin pH (ApH)}

Table 1 displays that storage period, season and all two-way interactions except for storage period and marketing channel had a significant $(p \leq 0.05)$ effect on $\mathrm{ApH}$, which increased significantly with increased storage period, and egg obtained in the summer had significantly $(p \leq 0.01)$ higher $\mathrm{ApH}$ compared to those bought in the winter (Table 1). Eggs obtained from supermarkets and grocery stores had statistically similar values. Figure 8 shows that eggs obtained in the summer season and stored for 14 days or those bought in the winter season and not stored had significantly $(p \leq 0.05)$ the highest and the lowest $\mathrm{ApH}$, respectively, and the eggs obtained in the winter and stored for 14 days had statistically similar $\mathrm{ApH}$, as those acquired in the summer and stored for 0 and 7 days. On the other hand, eggs obtained in the winter and stored for 7 days had significantly $(p \leq 0.05)$ lower $\mathrm{ApH}$ than those obtained in the winter and stored for 14 days, or those obtained in the summer, and stored for 7 or 14 days. Figure 9 illustrates that eggs acquired from supermarket and grocery stores in the summer had statistically similar $\mathrm{ApH}$ values.

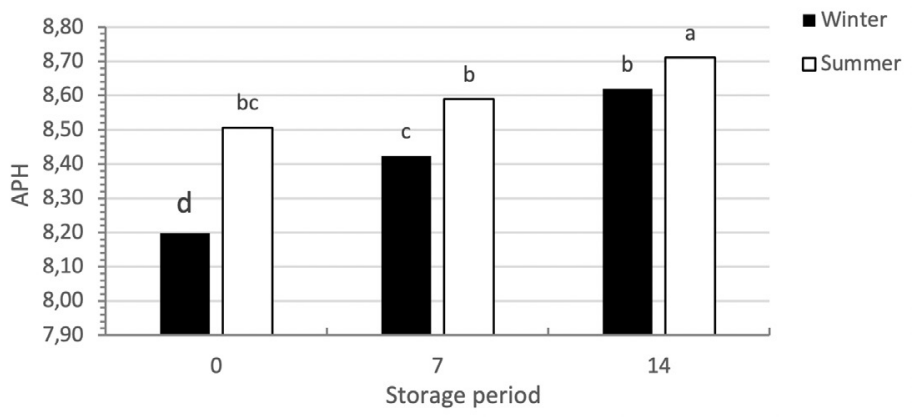

Figure $\mathbf{8}$ - The interaction effect of season and storage period on albumin $\mathrm{pH}$. 
Table 1 - Effect of storage period, marketing channel and season on internal egg quality.

\begin{tabular}{|c|c|c|c|c|c|c|c|}
\hline & & $\mathrm{HU}$ & YIND & YCLR & Y/A & $\mathrm{YpH}$ & $\mathrm{ApH}$ \\
\hline \multirow{4}{*}{$S P(d)$} & 0 & $69.45^{a}$ & $44.52^{a}$ & $5.97^{c}$ & $0.54^{c}$ & $7.01^{c}$ & $8.35^{c}$ \\
\hline & 7 & $64.54^{b}$ & $41.83^{b}$ & $6.40^{\mathrm{b}}$ & $0.56^{b}$ & $7.19^{b}$ & $8.51^{b}$ \\
\hline & 14 & $60.87^{c}$ & $40.15^{c}$ & $6.95^{a}$ & $0.60^{a}$ & $7.41^{\mathrm{a}}$ & $8.67^{a}$ \\
\hline & SEM & $0.319 \pm$ & $0.154 \pm$ & $0.068 \pm$ & $0.004 \pm$ & $0.018 \pm$ & $0.023 \pm$ \\
\hline \multirow{4}{*}{ C } & Supermarket & $68.16^{a}$ & $43.03^{a}$ & $5.99^{b}$ & $0.56^{a}$ & 7.21 & 8.49 \\
\hline & Grocery & $61.75^{b}$ & $41.31^{b}$ & $6.89^{a}$ & $0.57^{a}$ & 7.20 & 8.53 \\
\hline & SEM & $0.261 \pm$ & $0.126 \pm$ & $0.055 \pm$ & $0.003 \pm$ & $0.015 \pm$ & $0.019 \pm$ \\
\hline & Winter & $67.83^{a}$ & $43.62^{\mathrm{a}}$ & $7.05^{\mathrm{a}}$ & $0.54^{b}$ & $7.15^{b}$ & $8.41^{b}$ \\
\hline \multirow[t]{6}{*}{$S$} & Summer & $62.07^{b}$ & $40.71^{b}$ & $5.83^{b}$ & $0.59^{a}$ & $7.26^{\mathrm{a}}$ & $8.60^{\mathrm{a}}$ \\
\hline & SEM & $0.261 \pm$ & $0.126 \pm$ & $0.055 \pm$ & $0.003 \pm$ & $0.015 \pm$ & $0.019 \pm$ \\
\hline & Mean & 64.95 & 42.17 & 6.44 & 0.56 & 7.20 & 8.51 \\
\hline & SEM & \pm 0.237 & \pm 0.110 & \pm 0.046 & \pm 0.003 & \pm 0.011 & \pm 0.014 \\
\hline & St & $<.0001$ & $<.0001$ & $<.0001$ & $<.0001$ & $<.0001$ & $<.0001$ \\
\hline & C & $<.0001$ & $<.0001$ & $<.0001$ & 0.218 & 0.5458 & 0.1384 \\
\hline \multirow[t]{5}{*}{$p$ Value } & $S$ & $<.0001$ & $<.0001$ & $<.0001$ & $<.0001$ & $<.0001$ & $<.0001$ \\
\hline & $C * S T$ & $<.0001$ & 0.112 & 0.795 & 0.1919 & 0.7348 & 0.7569 \\
\hline & $S * S T$ & 0.0101 & 0.618 & 0.472 & 0.1703 & 0.6964 & 0.0031 \\
\hline & $\mathrm{S}^{*} \mathrm{C}$ & 0.0002 & 0.869 & $<.0001$ & 0.0004 & 0.0008 & 0.0139 \\
\hline & $S * C * S T$ & 0.4780 & 0.004 & 0.490 & 0.965 & 0.9168 & 0.1169 \\
\hline
\end{tabular}

SEM: standard error of means. SP: storage period; C: marketing channel; S: season; HU: Haugh unit values; YIND: yolk index; YCLR: yolk color grade; Y/W: yolk albumin ratio; YpH; yolk $\mathrm{pH} ; \mathrm{ApH}$ : albumin $\mathrm{pH}$. a-c Values in the same column with the same factor, with different superscript letters differ significantly $(p \leq 0.05)$.

\section{Specific gravity (SG*10)}

Table 2 displays that storage length, season and their interaction had a significant $(p \leq 0.01)$ effect on $S G$, that decreased with increased storage period, while egg bought from supermarket and grocery stores had statistically similar values (Table 2 ). Eggs obtained in the in winter had significantly $(p \leq 0.05)$ higher SG than those acquired in the summer. Figure 9 shows that eggs stored in the winter had significantly $(p \leq 0.05)$ higher SG than their peers stored in the summer, and eggs stored in the winter for 0 and 14 days had significantly $(p \leq 0.05)$ the highest and lowest SG, respectively. Similar result was observed for eggs procured in the summer and stored for the same periods (Figure10).

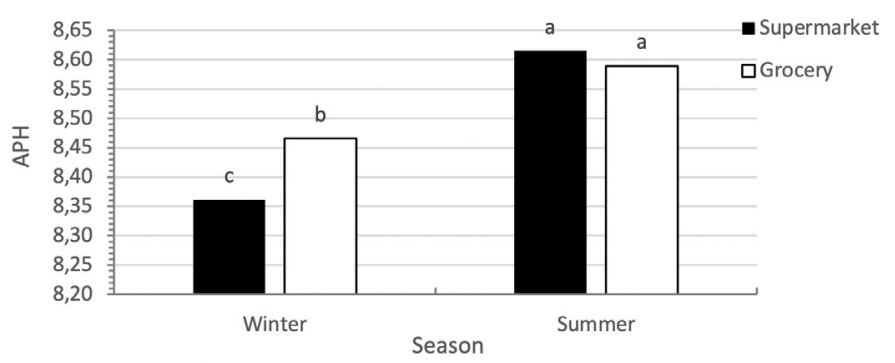

Figure 9 - The interaction effect of season and marketing channel on albumin $\mathrm{pH}$.

\section{Shape index (SI)}

Only marketing channels significantly $(p \leq 0.01)$ affected egg SI, and eggs obtained from grocery stores had significantly higher SI than those obtained from supermarkets, whereas eggs bought in the summer and winter or stored for different periods had statistically similar SI (Table 2).

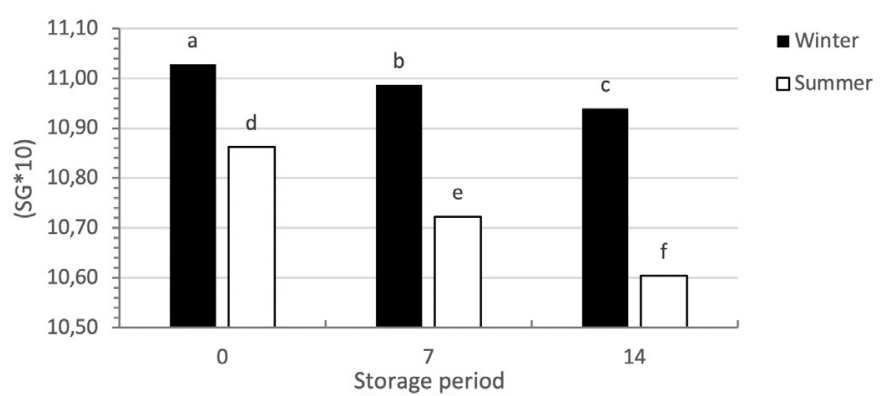

Figure 10 - The interaction effect of season and storage period on specific gravity.

\section{Shell thickness (ST*10)}

The data in Table 2 exhibit that only storage length, season and the interaction between season and channels of marketing had a significant $(p \leq 0.01)$ effect on ST, which decreased with increased storage length, but eggs obtained from grocery and supermarkets stores had similar values. On the other hand, eggs purchased in the winter had significantly $(p \leq 0.05)$ higher ST than those bought in the summer (Table 2). According to (Figure 11) eggs bought from supermarket stores had significantly $(p \leq 0.05)$ the highest and lowest ST in the winter and summer, respectively. Furthermore, eggs obtained from grocery stores had significantly $(p \leq 0.05)$ higher ST in the winter than in the summer. 
Alshaikhi AM, Abdullatif AA, Badwi MA, Alsobayel AA
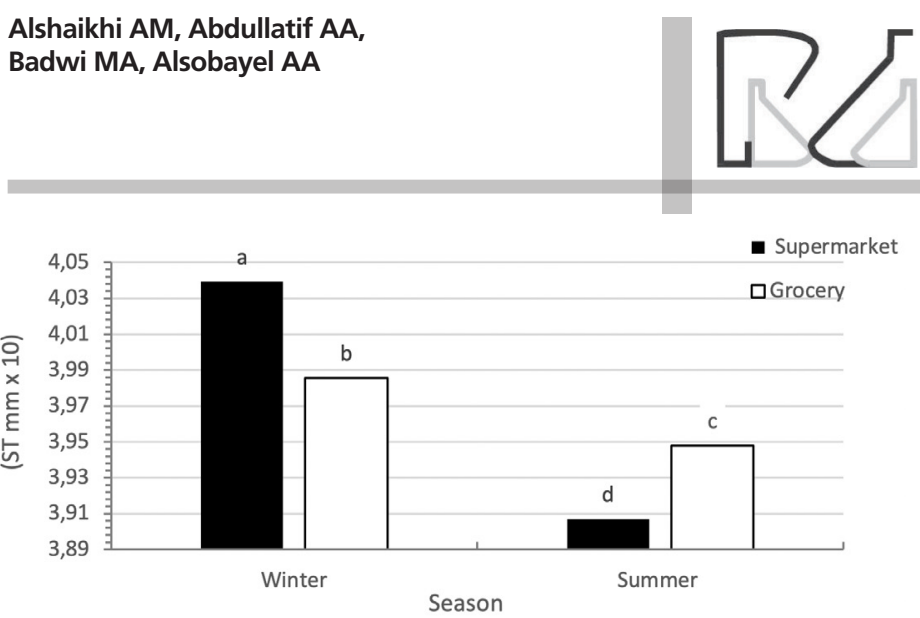

Figure 11 - The interaction effect of season and marketing channel on shell thickness.

\section{Egg surface area (SA)}

The upshots in Table 2 specify that storage length, channel of marketing, season and the interaction between season and marketing channel had a significant $(p \leq 0.01)$ effect on $S A$, and significantly $(p \leq 0.05)$ reduced with raised storage length, but eggs stored for 0 or 7 days had statistically similar values. SA of eggs bought from grocery stores or in the winter had significantly $(p \leq 0.05)$ greater values than those obtained from supermarkets and in the summer, respectively (Table 2). Figure 12 shows that eggs procured from grocery stores had significantly $(p \leq 0.05)$ the highest and lowest egg SA in the winter and summer, respectively, while eggs obtained from supermarkets had significantly $(p \leq 0.05)$ lower SA in the winter than in the summer.

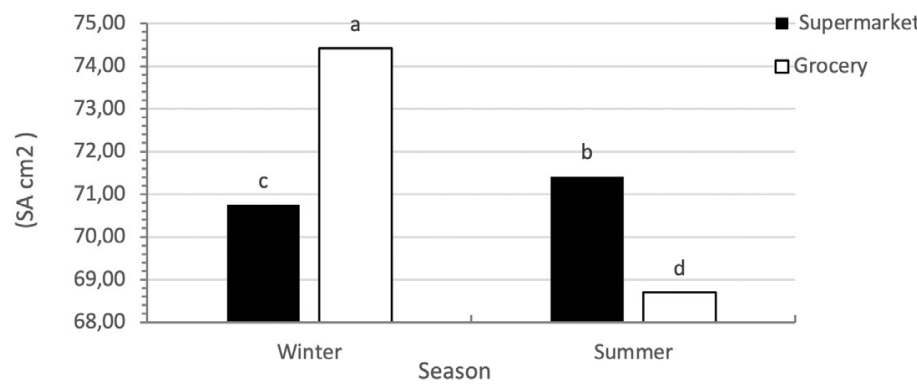

Figure 12 - The interaction effect of season and marketing channel on egg surface area.

\section{Shell density (SD)}

Only season and all second order interaction had a significant $(p \leq 0.01)$ effect on SD, and eggs bought from supermarket and grocery stores and stored for different days had statistically similar SD values (Table 2). Eggs obtained in the winter had significantly higher values than those acquired in the summer. Eggs bought from supermarkets in the winter and stored for 14 days tended to have the highest SD, whereas those found in grocery stores in the summer, and stored for seven days tend to have the lowermost value (Figure 13).
Effects of Storage Period, Marketing Channels and Season on Internal and External Quality of Commercial Table Eggs Marketed in Riyadh City (Saudi Arabia)

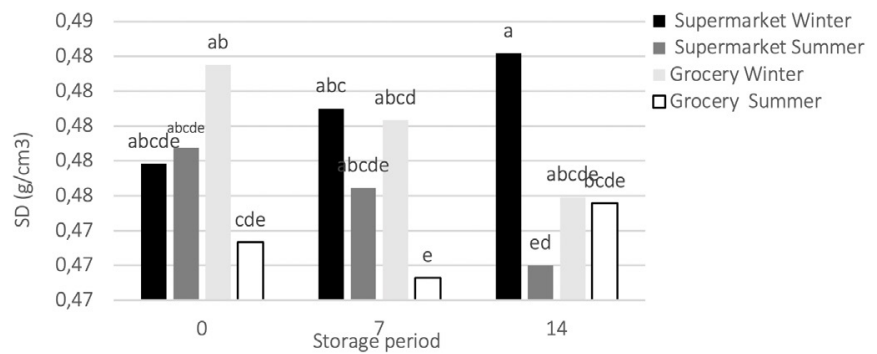

Figure 13 - The interaction effect of storage period, marketing channels and season on shell density.

\section{Shell weight per unit of surface area (SWUSA)}

Table 2 confirms that storage period, season, interaction between season and marketing channels, and all two - way interaction had a significant $(p \leq 0.01)$ effect on SWUSA, which were reduced with increased storage period. SWUSA of eggs procured from supermarket and grocery stores had statistically similar values, but eggs obtained in the winter had a significant $(p \leq 0.05)$ higher SWUSA than those acquired in the summer (Table 2). Eggs obtained in the supermarkets had significantly $(p \leq 0.05)$ the lowest SWUSA in the summer, while eggs bought from grocery stores in the summer had statistically similar SWUSA as those obtained from both channels in the winter (Figure14). Eggs procured from the supermarket in the winter and not stored had significantly $(p \leq 0.05)$ the highest SWUSA, while those bought from supermarkets in the summer and sored for 14 days had the lowest value. Eggs obtained from the supermarket in the winter and not stored had significantly $(p \leq 0.05)$ the highest SWUSA, while those found in supermarkets in the summer and stored for 14 days had the lowest value (Figure15).

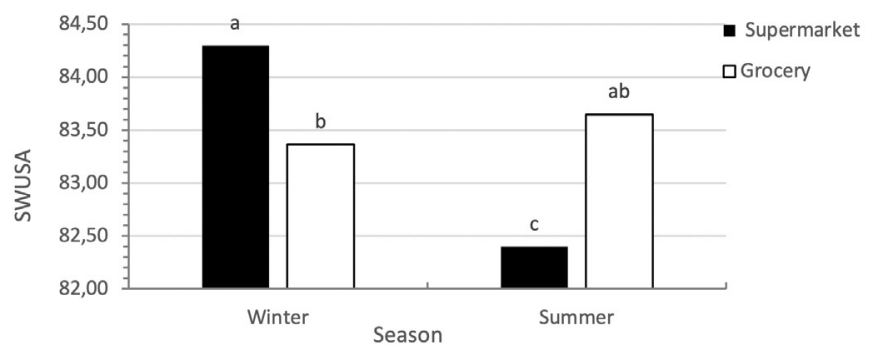

Figure 14 - The interaction effect of season and marketing channel on shell weight per unit of surface area

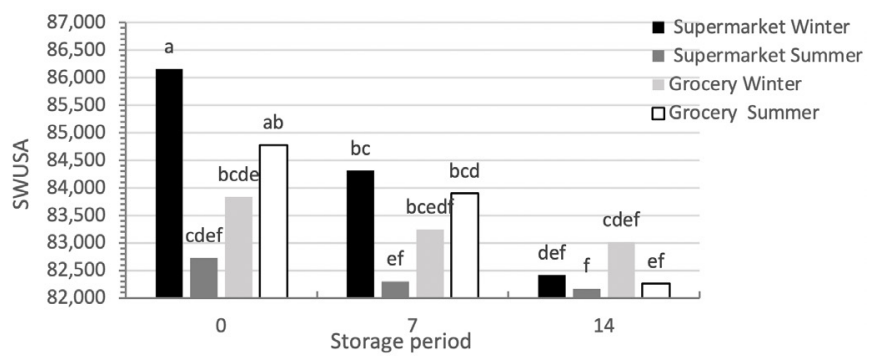

Figure 15 - The interaction effect of storage period, marketing channels and season on shell weight per unit of surface area. 


\section{Air cell depth (AC)}

It appears from Table 2 that the storage length, marketing channels, season and the interaction between marketing channels and storage period had a significant $(p \leq 0.01)$ effect on $A C$, that decreased with increased storage period, whereas $A C$ of eggs bought from grocery or in the summer had a significant $(p \leq 0.05)$ upper value than those obtained from the supermarket or in the winter, respectively. Figure 16 shows that eggs obtained from supermarkets and grocery stores and stored for 0 and 14 days had significantly $(p \leq 0.05)$ the lowest and the highest $A C$, respectively. On the other hand, eggs obtained in grocery stores and stored for 7 days had significantly $(p \leq 0.05)$ higher AC values than their peers bought from supermarkets.

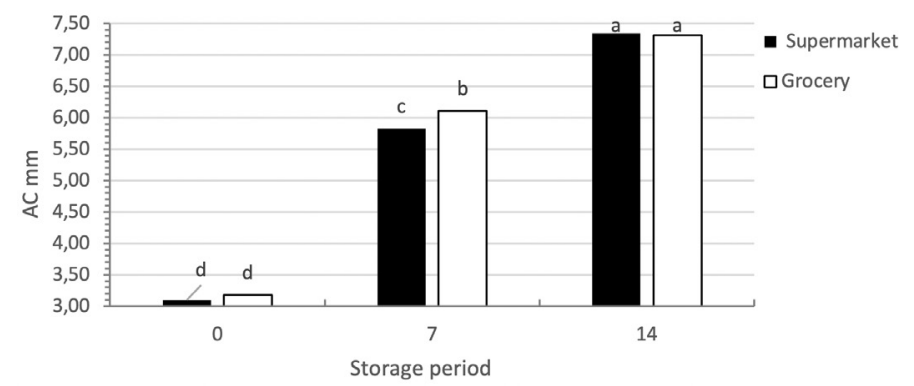

Figure 16 - The interaction effect of season and storage period on air cell depth

Table 2 - Effect of storage period marketing channel and season on the external egg quality.

\begin{tabular}{|c|c|c|c|c|c|c|c|c|}
\hline & & SG & $\mathrm{SI}$ & ST & SA & SD & SWUSA & $A C$ \\
\hline \multirow{4}{*}{$S P(d)$} & 0 & $10.95^{\mathrm{a}}$ & 76.19 & $4.02^{a}$ & $71.75^{a}$ & 0.48 & $84.38^{a}$ & $3.14^{c}$ \\
\hline & 7 & $10.85^{b}$ & 76.09 & $3.97^{b}$ & $71.42^{\mathrm{a}}$ & 0.48 & $83.44^{b}$ & $5.97^{b}$ \\
\hline & 14 & $10.77^{c}$ & 76.38 & $3.92^{c}$ & $70.79^{b}$ & 0.48 & $82.47^{c}$ & $7.33^{\mathrm{a}}$ \\
\hline & SEM & $0.007 \pm$ & $0.142 \pm$ & $0.011 \pm$ & $0.143 \pm$ & $0.002 \pm$ & $0.037 \pm$ & $0.286 \pm$ \\
\hline \multirow{3}{*}{ C } & Supermarket & 10.86 & $75.38^{b}$ & 3.97 & $71.08^{b}$ & 0.48 & 83.51 & $5.42^{b}$ \\
\hline & Grocery & 10.86 & $76.64^{a}$ & 3.97 & $71.56^{a}$ & 0.48 & 83.35 & $5.53^{\mathrm{a}}$ \\
\hline & SEM & $0.006 \pm$ & $0.116 \pm$ & $0.009 \pm$ & $0.117 \pm$ & $0.001 \pm$ & $0.030 \pm$ & $0.233 \pm$ \\
\hline \multirow{3}{*}{$S$} & Winter & $10.98^{\mathrm{a}}$ & 76.24 & $4.01^{a}$ & $72.59^{a}$ & $0.48^{a}$ & $83.83^{a}$ & $5.40^{b}$ \\
\hline & Summer & $10.73^{b}$ & 76.20 & $3.93^{b}$ & $70.06^{b}$ & $0.47^{b}$ & $83.02^{b}$ & $5.55^{\mathrm{a}}$ \\
\hline & SEM & $0.006 \pm$ & $0.116 \pm$ & $0.009 \pm$ & $0.117 \pm$ & $0.001 \pm$ & $0.030 \pm$ & $0.233 \pm$ \\
\hline \multirow{9}{*}{$p$ Value } & Mean & 10.86 & 76.22 & 3.97 & 71.32 & 0.48 & 83.43 & 5.48 \\
\hline & SEM & \pm 0.006 & \pm 0.083 & \pm 0.006 & \pm 0.099 & \pm 0.001 & \pm 0.167 & \pm 0.051 \\
\hline & St & $<.0001$ & 0.3509 & $<.0001$ & $<.0001$ & 0.7967 & $<.0001$ & $<.0001$ \\
\hline & c & 0.7492 & $<.0001$ & 0.6038 & 0.0042 & 0.3367 & 0.6301 & 0.01 \\
\hline & $S$ & $<.0001$ & 0.8117 & $<.0001$ & $<.0001$ & 0.001 & 0.0145 & 0.0006 \\
\hline & $C * S T$ & 0.8065 & 0.2926 & 0.9467 & 0.9448 & 0.7582 & 0.8137 & 0.0112 \\
\hline & $S * S T$ & $<.0001$ & 0.0568 & 0.6872 & 0.8468 & 0.8748 & 0.6311 & 0.5019 \\
\hline & $S^{*} C$ & 0.426 & 0.121 & 0.0002 & $<.0001$ & 0.733 & 0.001 & 0.516 \\
\hline & $S^{*} C * S T$ & 0.875 & 0.313 & 0.622 & 0.613 & 0.027 & 0.009 & 0.056 \\
\hline
\end{tabular}

SEM: standard error of means. SP: storage period; C: marketing; S: season; SG*10: specific gravity; SI: shape index; ST: shell thickness (mm x 10); SA; egg surface area (cm2); SD: shell density $(\mathrm{g} / \mathrm{cm} 3)$; SWUSA: shell weight per unit of surface area (mg/cm2; AC; cell depth ( $\mathrm{mm}$. a-c Values in the same column with same factor, with different superscript letters differ.

\section{DISCUSSION}

Our study showed that seven and fourteen days of storage period led to a significant $(p \leq 0.05)$ decrease in Haugh unit values, yolk index, specific gravity, shell thickness and shell weight per unit of surface area, and increase in yolk color grade, yolk albumin ratio, yolk and albumin $\mathrm{pH}$ and air cell depth, nevertheless shape index and shell density were not affected by storage length. The results also showed that the rate of change in traits values increased with increased storage periods. Several investigators stated similar storage length effect with respect to Haugh unit values and yolk index Haugh unit values and yolk index (Drabik et al., 2018; Lall et al., 2018; Samli et al., 2005; Yildirim, 2017), yolk color grade (Lee et al., 2016), yolk albumin ratio (Hermiz et al., 2012; Moula et al., 2009), yolk and albumin pH (Drabik et al., 2018), specific gravity and air cell depth (Alsobayel \& Albadry, 2011; Samli et al., 2005) and shell thickness (Khatun et al., 2016; Monira et al., 2003). In dissimilarity to our results, some investigators reported that the storage period had no effect regarding the yolk color grade (Alsobayel \& Albadry, 2011; Stojčić \& Perić, 2018), yolk albumin ratio (Khatun et al., 2016), albumin pH (Lee et al., 2016) shell thickness and shell surface area (Yildirim 2017). However, some other investigators reported that the storage period led to a significant increase regarding the shell weight per unit of surface area (Alsobayel \& Albadry, 2011), shell density (Lee et al., 2016; Alsobayel \& Albadry, 2011), and shell thickness (Lall et al., 2018) and decrease in yolk color grade (Kralik et al., 2014; Drabik et al., 2018), with increased storage period. The differences between our results 
Alshaikhi AM, Abdullatif AA, Badwi MA, Alsobayel AA
Effects of Storage Period, Marketing Channels and Season on Internal and External Quality of Commercial Table Eggs Marketed in Riyadh City (Saudi Arabia)

be purchased from supermarket stores, and not stored for more than 1 week in the refrigerator under $4-6^{\circ} \mathrm{C}$ and at $40-60 \%$ relative humidity.

\section{ACKNOWLEDGEMENTS}

The authors would like to thank Deanship of scientific research in King Saud University for funding and supporting this research through the initiative of DSR Graduate Students Research Support (GSR).

\section{CONFLICT OF INTEREST}

The authors declare there are no conflict of interests. investigators have reported significant differences in egg quality characteristics of eggs bought from different channels of marketing (Alshaikhi et al., 2019; Alsobayel et al., 2020; Attia et al., 2014; Ewonetu \& Negassi, 2016; Kara Ali et al., 2014; Moula et al., 2013; Omar \& Aref 2000; Tolimir et al., 2017).

On the other hand, eggs obtained in the winter showed significantly $(p \leq 0.05)$ greater Haugh unit values, yolk index, specific gravity, shell thickness, shell density, shell weight per unit of surface area and yolk color, and lower yolk albumin ratio, air cell depth albumin and yolk $\mathrm{pH}$ than those acquired in the summer season. Several investigators reported similar season effects regarding yolk color (Simeon et al., 2018) specific gravity, shell weight per unit of egg surface area (Izat et al., 1985) and shell thickness (Islam et al., 2001; Moula et al., 2013). In contrast to our results, Izat et al., (1985) reported that shell density was higher in the winter, but some other investigators reported no significant season effect regarding the Haugh unit values, (Izat et al., 1986; Simeon et al., 2018) yolk color grades and yolk albumin ratio (Moula et al., 2013). These differences might be due to different strains, age of the birds, size of the egg, nutrition, heat stress and egg poor handling on farm and marketing channels.

\section{CONCLUSION}

From the results of the study reported herein and under the experiment conditions, we conclude that storage period, marketing channel and season play a significant role in affecting quality traits of Table eggs marketed in Riyadh city. Table eggs purchased from supermarkets or during the winter season showed better quality than those from grocery stores and in the summer season. Storage of Table eggs for more than one week in refrigerators had a pronounced adverse effect on Table egg quality characteristics. Therefore, in order to have good quality of Table eggs, eggs should

\section{REFERENCES}

Al-Obaidi FA, Al-Shadeedi SM, Al-Dalawi RH, Center A. Quality, chemical and microbial characteristics of table eggs at retail stores in Baghdad. International Journal of Poultry Science 2011;10(5):381-385.

Alshaikhi A M. Quality evaluation of commercial table eggs marketed in riyadh city during winter and summer seasons [thesis]. Riyadh (SA): King Saud University; 2019.

Alsobayel A, Albadry M. Effect of storage period and strain of layer on internal and external quality characteristics of eggs marketed in Riyadh area. Journal of the Saudi Society of Agricultural Sciences $2011 ; 10(1): 41-45$

Alsobayel AA, Alshaikhi AM, Al-Abdullatif AA. Quality and weight grades classification of stored commercial Table eggs marketed in supermarket and grocery stores in Riyadh city during winter and summer seasons according to GCC standard. Journal of the Saudi Society of Agricultural Sciences 2020;19(5):339-352.

Attia YA, Al-Harthi MA, Shiboob MM. Evaluation of quality and nutrient contents of table eggs from different sources in the retail market. Italian Journal of Animal Science 2014;13(2):3294.

Bessadok A, Khochilef I, El Gazzah M. Etat des ressources génétiques de la population locale du poulet en Tunisie. Tropicultura 2003;21(4):167172.

Calik J. Changes in quality traits of eggs from yellowleg partridge ((z) over dot-33) laying hens depending on storage conditions of eggs. Zywnosc-nauka Technologia Jakosc 2013;20(2):73-79.

Carter TC. The hen's egg: Estimation of shell superficial area and egg volume, using measurements of fresh egg weight and shell length and breadth alone or in combination. British Poultry Science 1975;16(5):541-543.

Curtis P, Gardner F, Mellor DJPS. A comparison of selected quality and compositional characteristics of brown and white shell eggs: I. Shell quality. Poultry Science1985;64(2):297-301.

Drabik K, Chabroszewska P, Vasiukov K, Adamczuk A, Batkowska J. Glycerin as a factor for moderating quality changes in table eggs during storage. Archiv fuer Tierzucht 2018;61(3):285

Ewonetu K, Negassi A. Evaluation of external and internal quality of chicken table eggs at retailers in Eastern Ethiopia. Journal of Animal Science Advances 2016;6(5):1642-1649.

GASTAT. General Authority for statistics. Kingdom of Saudi Arabia; 2017. 
Haugh RR. The Haugh unit for measuring egg quality. United States Egg and Poultry Magazine 1937;43:522-555.

Hermiz HN, Ali SH. Effect of strain and storage period on some qualitative and quantitative traits of table eggs. World Academy of Science, Engineering and Technology International Journal of Nutrition and Food Engineering 2012;6(8):1589-1593.

Islam M, Bulbul S, Seeland G, Islam A. Egg quality of different chicken genotypes in summer and winter. Pakistan Journal of Biological Sciences 2001;4:1411-1414

Izat A, Gardner F, Mellor D. Effects of age of bird and season of the year on egg quality 1 . Shell quality. Poultry Science 1985;64(10):1900-1906.

Izat A, Gardner F, Mellor D. The effects of age of bird and season of the year on egg quality. II. Haugh units and compositional attributes. Poultry Science 1986;65(4):726-728

Jones D. Egg functionality and quality during long-term storage. International Journal of Poultry Science 2007;6(3):157-162.

Kara AM, Ait KA, Milet A, Moula N. Quality assessment of marketed eggs in Eastern Algeria. Nature \& Technologie 2014;11(2):52-58.

Khatun $H$, Rashid M, Faruque S, Islam M, Ali M. Study on egg quality characteristics of three commercial layer strains under different storage conditions 2016. International Journal of Animal Resources 2016;1(2):63-70

Kralik Z, Kralik G, Grčević M, Galović D. Effect of storage period on the quality of table eggs. Acta Agraria Kaposvariensis 2014;18(1):200-206.

Lall JG, Santra AK, Sahu SS. Effect of storage period on internal and external parameters of Deshi Chicken fowl. Journal of Applied and Natural Science 2018;10(1):41-44

Lee $\mathrm{MH}$, Cho EJ, Choi ES, Sohn SH. The effect of storage period and temperature on egg quality in commercial eggs. Korean Journal of Poultry Science 2016;43(1):31-38.

Mohiti-Asli M, Shariatmadari F, Lotfollahian H, Mazuji MTJCJoAS. Effects of supplementing layer hen diets with selenium and vitamin $\mathrm{E}$ on egg quality, lipid oxidation and fatty acid composition during storage. Canadian Journal of Animal Science 2008;88(3):475-83.

Monira K, Salahuddin M, Miah GJIJPS. Effect of breed and holding period on egg quality characteristics of chicken. International Journal of Poultry Science 2003;2(4):261-263.
Moula N, Ait-Kaki A, Leroy P, Antoine-Moussiaux N. Quality assessment of marketed eggs in Bassekabylie (Algeria). Brazilian Journal of Poultry Science 2013:15(4):395-399.

Moula N, Antoine-Moussiaux N, Farnir F, Leroy PJIJops. Comparison of egg composition and conservation ability in two Belgian local breeds and one commercial strain. International Journal of Poultry 2009;8(8):768774.

Moula N. Biodiversité avicole dans les pays industrialisés et en développement: caractérisation et étude des performances de production de races gallines locales [thesis]. Liège $(B E)$ : Université de Liège; 2012.

North M, Bell D. Commercial chicken production manual. New York: Nostrand, Reinhold; 1990.

Omar J, Aref R. Some quality characteristics of eggs marketed in North of West Bank (Palestine). Revue Médecine Vétérinaire 2000;151(1):47-50.

Opaliński S. Supplemental iodine. In: Hester PY, editor. Egg innovations and strategies for improvements. San Diego: Academic Press; 2017. p.393402.

Samli H, Agma A, Senkoylu N. Effects of storage time and temperature on egg quality in old laying hens. Journal of Applied Poultry Research 2005:14(3):548-553.

SAS. Institute's SAS user's guide. Version 5. Cary: SAS Institute; 2008.

Simeon R, Milun PD, Snežana B-B, Zdenka Š, Lidija P, Vladimir D, et al., Effect of age and season on production performance and egg quality of laying hens from different rearing systems. JAPS: Journal of Animal \& Plant Sciences 2018;28(6).

Stojčić MĐ, Perić L. Influence of the storage period on the quality characteristics of table eggs. Contemporary Agriculture 2018;67(3/4):202-206.

Tolimir N, Maslovarić M, Škrbić Z, Lukić M, Rajković B, Radišić R. Consumer criteria for purchasing eggs and the quality of eggs in the markets of the city of Belgrade. Biotechnology in Animal Husbandry 2017;33(4):425437.

Yildirim A. Changes in quality characteristics during storage time of eggs from layer hens fed diet supplemented with Panax ginseng Meyer leaf extract. Progress in Nutrition 2017;19(2):197-204. 
